\title{
International Union for the Study of Social Insects report of Secretary-General Madeleine Beekman
}

\section{Annual Report}

Covering the period January 1-December 14, 2015

The Financial Subcommittee (Joan Herbers, Mark Brown and Heike Feldhaar), in consultation with me, decided not to offer travel grants to sections until 2018. We made that decision because we want to build a solid financial base to support attendance to the International Congress in Brazil in 2018. My financial report is therefore straightforward. Note that payments for review articles published in 2015 will be paid in early 2016 due to logistical reasons.

Financial Statement for the period January 1, 2015December 14, 2015 (all in US\$).
Beginning balance. $\$ 32,266.45$ Income

Springer payments. $\$ 42,984.81$

Interest $\$ 16.81$

Total income. $\$ 43,001.62$

Expenses

Best paper award $\$ 1000.00$

Office expenses. $\$ 1147.30$

Professional fees. $\$ 250.00$

Government fees........................................... $\$ 50.00$

Bank fees................................................... $\$ 235.00$

Total expenses................................................ \$2682.30

Ending balance.

Respectfully submitted, Madeleine Beekman, Secretary-General 